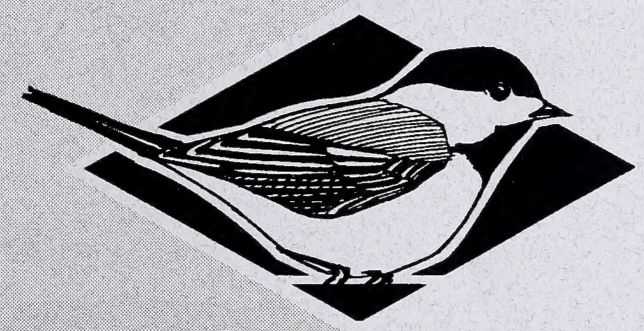

\title{
Status of the Wolverine (Gulo gulo) in Alberta
}

Stephen Petersen
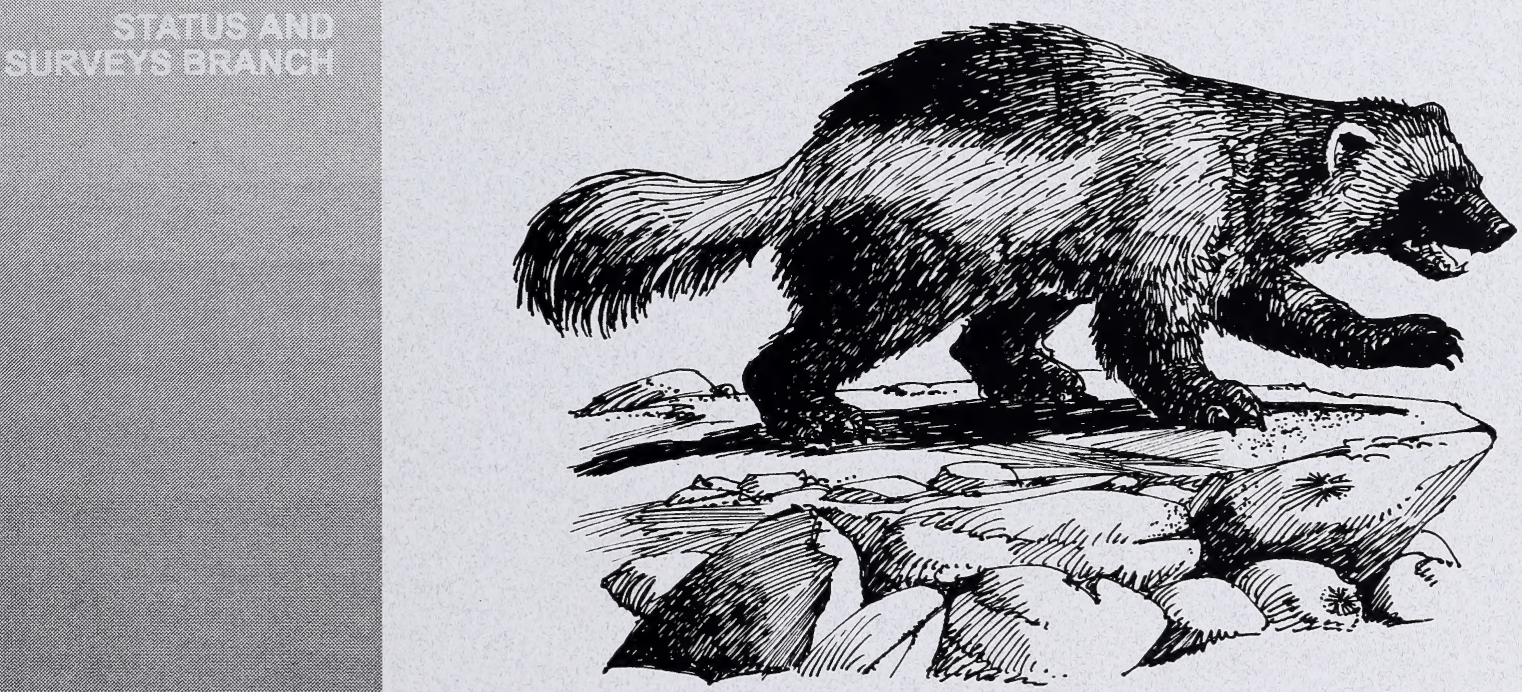

Alberta Wildlife Status Report No. 2 
Digitized by the Internet Archive in 2015 


\section{Status of the Wolverine (Gulo gulo) in Alberta}

Stephen Petersen

Alberta Wildlife Status Report No. 2

Published By:

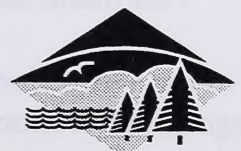


Publication No. T/364

ISBN: 0-7732-5124-3

ISSN: $1206-4912$

Series Editor: David R. C. Prescott

Illustrations: Brian Huffman

For copies of this report, contact:

Information Centre - Publications

Alberta Environmental Protection

Natural Resources Service

Main Floor, Bramalea Building

9920 - 108 Street

Edmonton, Alberta, Canada T5K 2M4

Telephone: (403) 422-2079

OR

Communications Division

Alberta Environmental Protection

\#100, 3115 - 12 Street NE

Calgary, Alberta, Canada T2E 7J2

Telephone: (403) 297-3362

This publication may be cited as:

Petersen, S. 1997. Status of the Wolverine (Gulo gulo) in Alberta. Alberta Environmental Protection, Wildlife Management Division, Wildlife Status Report No. 2, Edmonton, AB.

$17 \mathrm{pp}$. 


\section{PREFACE}

Every five years, the Wildlife Management Division of Alberta Natural Resources Service reviews the status of wildlife species in Alberta. These overviews, which have been conducted in 1991 and 1996, assign individual species to "color" lists which reflect the perceived level of risk to populations which occur in the province. Such designations are determined from extensive consultations with professional and amateur biologists, and from a variety of readily-available sources of population data. A primary objective of these reviews is to identify species which may be considered for more detailed status determinations.

The Alberta Wildlife Status Report Series is an extension of the 1996 Status of Alberta Wildlife review process, and provides comprehensive current summaries of the biological status of selected wildlife species in Alberta. Priority is given to species that are potentially at risk in the province (Red or Blue listed), that are of uncertain status (Status Undetermined), or which are considered to be at risk at a national level by the Committee on the Status of Endangered Wildlife in Canada (COSEWIC).

Reports in this series are published and distributed by the Wildlife Management Division of Alberta Environmental Protection, and are intended to provide detailed and up-to-date information which will be useful to resource professionals for managing populations of species and their habitats in the province. The reports are also designed to provide current information which will assist the proposed Alberta Endangered Species Conservation Committee to identify species that may be formally designated as endangered or threatened under the Alberta Wildlife Act. To achieve these goals, the reports have been authored and/or reviewed by individuals with unique local expertise in the biology and management of each species. 


\section{EXECUTIVE SUMMARY}

The Wolverine is a medium-sized carnivore and one of the largest members of the family Mustelidae. The species occupies vast areas of the tundra and boreal forest in North America, Scandinavia and Asia, at very low densities. Wolverines are considered to be scavenging predators because they feed largely on carrion, but they will also consume berries, insects, birds, and rodents. The reliance on carrion limits the number of individuals that an area can support, and this has led to an extremely dispersed population. The home range of a male Wolverine can be larger than $1500 \mathrm{~km}^{2}$ and may contain a number of female home ranges. Not only are Wolverine populations small, but the species has a low reproductive output because of poor breeding success, high juvenile mortality and slow sexual maturity.

The Wolverine has always been considered scarce and presently its range is being reduced by human encroachment. Wolverines have been extirpated from large portions of their range in southern and eastern Canada and are now considered to be "endangered" in eastern regions of this country. Western and northern Canada have healthier populations, although the Wolverine is considered to be "vulnerable" in these areas, and at risk of further population declines and range contractions.

Wolverines were once found across Alberta, but are now restricted to the northern half of the province and along the mountains and foothills. Trapping data suggest that the highest populations are found in the western parts of the province, and that populations have declined in most regions of Alberta in the past two decades. Among the limiting factors for Wolverines in Alberta are the loss of isolated habitat, a reduction in the availability of large ungulate carrion, and trapping pressure. To date, no studies have been conducted on Wolverines in Alberta. This lack of information, along with recent declines in trapping harvest, has led to the inclusion of the Wolverine on the "Blue List" of species that may be at risk in the Alberta. Almost all information on Wolverines in this province has been derived from trapping data, and current management is restricted to the setting of trapping season and quotas. Additional research is needed to better define the status of this species in Alberta. 


\section{ACKNOWLEDGEMENTS}

I am indebted to the following people who have helped in the creation of this report through contributing current information or by reviewing earlier versions of this document: Steve Brechtel, Bill Johnson, Floyd Kunnas, Bruce Treichel, Arlen Todd and David Prescott (Alberta Natural Resources Service), Mikhail S. Blinnikov (Center for Russian Nature Conservation, and Biodiversity Conservation Center of Russia), Chuck Dauphine (Committee On the Status of Endangered Wildlife in Canada), Doug Skinner (Westworth, Brusnyk and Associates), Harold Bryant (Provincial Museum of Alberta), Wes Bradford (Parks Canada) and Richard Moses, Jason Fisher and Dave Dansereau (University of Alberta). I also thank J. Horb for producing the maps, and D. Ryerson (Alberta Natural Resources Service) for editorial assistance.

Preparation of this report was funded by the Wildlife Management Enhancement Fund of Alberta Natural Resources Service and the Alberta Conservation Association. 


\section{TABLE OF CONTENTS}

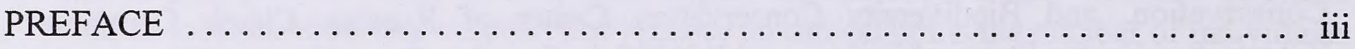

EXECUTIVE SUMMARY $\ldots \ldots \ldots \ldots \ldots \ldots \ldots \ldots \ldots \ldots \ldots \ldots \ldots \ldots \ldots \ldots \ldots \ldots \ldots \ldots$

ACKNOWLEDGEMENTS $\ldots \ldots \ldots \ldots \ldots \ldots \ldots \ldots \ldots \ldots \ldots \ldots \ldots \ldots \ldots \ldots \ldots \ldots$

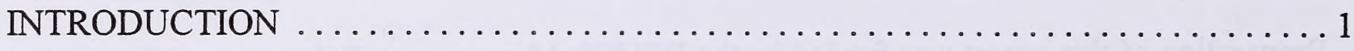

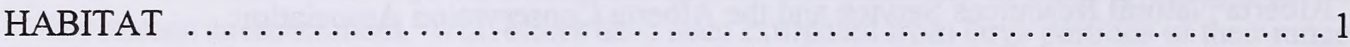

CONSERVATION BIOLOGY $\ldots \ldots \ldots \ldots \ldots \ldots \ldots \ldots \ldots \ldots \ldots \ldots \ldots \ldots \ldots \ldots \ldots \ldots$

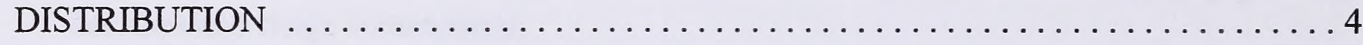

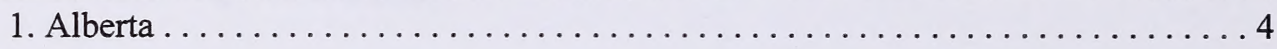

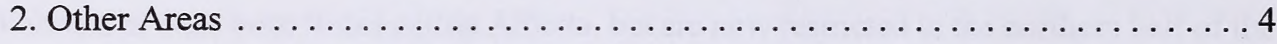

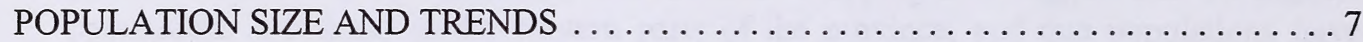

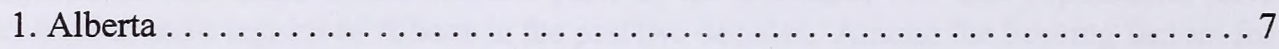

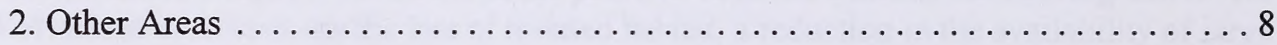

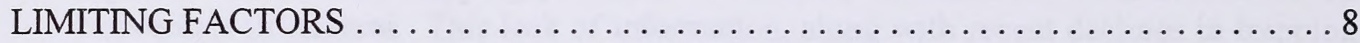

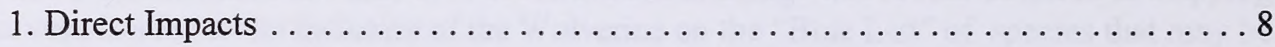

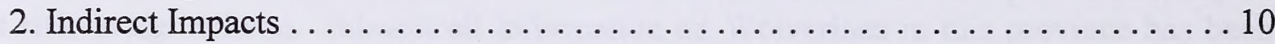

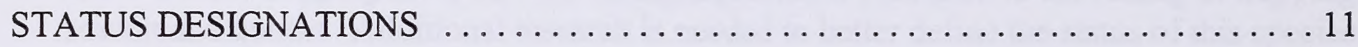

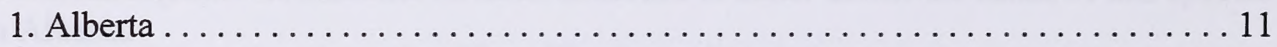

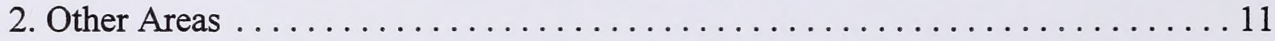

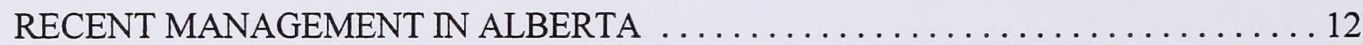

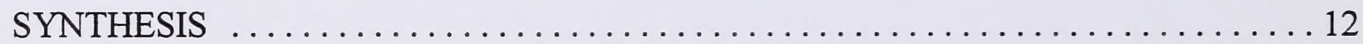

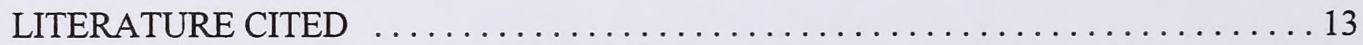

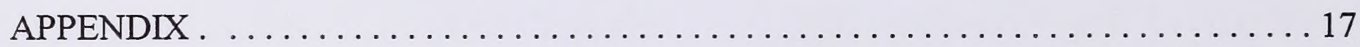




\section{INTRODUCTION}

The Wolverine or glutton (Gulo gulo L.) has a circumboreal distribution (Banfield 1974) but like most large carnivores, its range has contracted in recent years. On a global scale, the Wolverine is considered to be "vulnerable" (World Conservation Monitoring Center 1996), but its status on a regional scale varies. In eastern Canada, Wolverines are now considered to be "endangered" by the Committee on the Status of Endangered Wildlife in Canada (COSEWIC), whereas those in western and northern regions of the country are classified as "vulnerable" (COSEWIC 1996). In Alberta, the Wolverine is included on the provincial "Blue List" of species that may be at risk (Alberta Wildlife Management Branch 1996).

This report presents the most current information on the biology and conservation of the Wolverine in Alberta, as a first step in updating the status of this species in the province.

\section{HABITAT}

Historically, the Wolverine occurred in all of Canada's ecozones, and therefore was found in a wide variety of habitats. Although the range of this species has contracted in recent years (see "Distribution", below), it is still found in a diversity of ecozones, including the boreal forest, tundra, and subalpine regions. Furthermore, home ranges of Wolverines, which are typically hundreds of square kilometres in size (Banci 1987, Magoun 1985), usually encompass a variety of habitat types. It is therefore not surprising that specific habitat preferences for Wolverines have rarely been described. Rather, Wolverine density appears to be influenced more by food availability and proximity to humans than to specific attributes of the habitat (Banci 1994, Hatler 1989, Kelsall 1981).

Despite an absence of obvious habitat requirements, several aspects of habitat use by Wolverines have been noted. In Montana and south-central Alaska, Wolverines appear to occupy higher elevations during the summer than in winter, probably in response to changes in food availability (Gardner 1985, Hornocker and Hash 1981, Whitman et al. 1986). Hornocker and Hash (1981) found the Wolverines in Montana tended to cross clearcuts and natural openings in a straight line, as opposed to the slow, wandering movements used in forested areas. This observation, and the tendency of Wolverines to climb trees to escape from wolves (Boles 1977, Burkholder 1962), suggests that the availability of wooded areas may be important for avoiding predation. However, Banci (1978) found that Wolverines showed no reluctance to cross large natural openings in the southwestern Yukon, indicating that the availability of trees is not the most important aspect of habitat use in that area. The presence of trees is also not a factor in habitat use by Wolverines inhabiting tundra regions.

\section{CONSERVATION BIOLOGY}

The Wolverine is the largest terrestrial member of the mustelid family. Its pelage is dark brown, usually with two tan stripes

* See Appendix for definitions of selected status designations. 
running along the flanks and joining over the rump. The fur consists of dense under-fur from which long straight guard hairs protrude; the length and structure of these guard hairs make them exceptional at keeping the fur frost free (Hardy 1948, Quick 1952). This characteristic, as well as the beauty and rarity of Wolverine fur, makes it very valuable to arctic and subarctic peoples for parka trims (Hash 1987, Holbrow 1976, Kelsall 1981, Pasitschniak-Arts and Lariviere 1995, Quick 1952).

The Wolverine is both a scavenger and a predator, depending on the time of year. During the summer months, Wolverines are primarily predatory, with the most common prey being marmots, ground squirrels, mice, voles, birds and insects. Eggs and berries also may be included in the summer diet (Banci 1987, Doyle 1995, Gardner 1985, Hornocker and Hash 1981, Magoun 1985). During the winter, Wolverines are primarily scavengers and rely heavily on carrion of large ungulates killed by other predators or that have died of disease or starvation. However, live American Porcupines (Erethizon dorsatum), mice and voles may supplement their winter diet (Banci 1987, Gardner 1985, Hash 1987, Hornocker and Hash 1981, Magoun 1985), and Wolverines have been known to kill Caribou (Rangifer tarandus) and Moose (Alces alces) if snow conditions are favorable or if the prey is weakened (Burkholder 1962, Haglund 1966, Krott 1959, Pulliainen 1968). The importance of a large population of ungulates, and therefore a supply of carrion, seems to be critical to the survival of Wolverines during the winter (Banci 1994, Dauphine
1989, Hash 1987, Hatler 1989, Kelsall 1981).

Due to their scavenging lifestyle, Wolverines forage over large areas. Home range size is inversely related to the availability of food resources and will fluctuate with season, year, habitat type, age and sex (Banci 1987). In Alaska, annual home ranges for males range from $488 \mathrm{~km}^{2}$ to $917 \mathrm{~km}^{2}$, and average 666 $\mathrm{km}^{2}$ (Magoun 1985). In central Idaho, four adult males had an average home range size of $1525 \mathrm{~km}^{2}$ (Copeland 1996 in Weaver et al. 1996). Females have smaller home ranges than males. In Alaska for example, home ranges of females averaged $104 \mathrm{~km}^{2}$ (range: 53 to $232 \mathrm{~km}^{2}$, Magoun 1985). Females have even smaller home ranges while nursing young (Banci 1987, Gardner 1985, Hornocker and Hash 1981, Magoun 1985). Home ranges are arranged so that one male's range may encompass all or parts of several females' ranges (Banci 1987, Gardner 1985, Hornocker and Hash 1981, Magoun 1985). Home ranges of both males and females are marked using glandular secretions, scats and urine (Hatler 1989, Koehler et al. 1980). Wolverines have anal glands, plantar glands on the hind feet, and possibly an abdominal gland (Buskirk et al. 1986 in Banci 1994, Hall 1926). The function of scent marking may be to maintain spacing in time rather than space, notifying other individuals that an area is already being hunted (Koehler et al. 1980). Scent marking may also communicate information on the reproductive status of individuals (Banci 1994).

Although documented daily movements are generally small $($ mean $=1.5 \mathrm{~km}$, Banci 
1987), these estimates are straight-line distances obtained with telemetry, and may underestimate actual daily movements (Banci 1994, Hatler 1989, Magoun 1985). Magoun (1985) found that in Alaska, actual daily movements obtained by tracking were $33 \%$ greater than estimates calculated from straightline distances between telemetry relocations. Dispersing juveniles or transients will cover much greater distances than resident Wolverines. For example, one male moved $378 \mathrm{~km}$ in 20 months (Gardner 1985, Gardner et al. 1986), whereas Magoun (1985) documented a juvenile female that moved $300 \mathrm{~km}$ in four months (Magoun 1985). Sightings or trapping of animals far outside their normal range may represent such dispersal movements.

Wolverines are solitary animals except during the breeding season and while the female still has kits. Mating takes place between May and August with the peak in June (Banci and Harestad 1988, Blomqvist 1995, Liskop et al. 1981, Magoun and Valkenburg 1983, Mead et al. 1991, Mehrer 1976, Rausch and Pearson 1972). The long mating season is thought to increase the likelihood that the male can find all females that may be in his home range (Banci 1994, Hatler 1989, Magoun 1985).

Like most mustelids, Wolverines exhibit delayed implantation (Wright and Rausch 1955). After implantation, and a 30 to 40 day gestation period, the young are born in late February and early March (Banci and Harestad 1988, Blomqvist 1995, Liskop et al. 1981, Magoun and Valkenburg 1983, Mead et al. 1991, Mehrer 1976, Rausch and Pearson 1972).
Females usually dig a den under the snow down to ground level for the kits, or they may use blown-down trees or rock crevices that have been covered in snow (Hash 1987, Krott 1959, Magoun 1985, Pulliainen 1968). There is some indication that female Wolverines use the same area for denning in consecutive years (Lee and Niptanatiak 1996). Wolverines may be sensitive to human disturbances at this time, as females have been known to move their young to less secure dens to avoid human contact (Banci 1994, Pulliainen 1968). Kits are weaned in seven to eight weeks (Myhre and Myrberget 1975) and can attain adult size by the first winter, when they usually disperse (Hash 1987, Hatler 1989, Rausch and Pearson 1972).

Like most large carnivores, the reproductive potential of Wolverines is low. Major contributors to the low fecundity are juvenile mortality and poor breeding success (Hash 1987, Kelsall 1981). Up to six embryos have been found in the carcasses of trapped females, but the average litter size at birth is less than three in all studies conducted to date (Hatler 1989). Blomqvist (1995) found that the average litter size in captive Wolverines was 2.1. Magoun (1985) found that females produced an average of 0.6 offspring per year in Alaska. Rausch and Pearson (1972) estimated an average first-year mortality rate of 1.5 young per litter. Reproductive success of free ranging females of all age classes is heavily dependent on food availability (Banci 1987, Magoun 1985, 1987).

The Wolverine's low reproductive rate is also caused by relatively slow sexual maturity. In free-ranging Wolverines, 
females may breed by the age of two years (Hatler 1989), but a study of captiveborn Wolverines found that most females did not become sexually mature until 3.5 years of age (Blomqvist 1995). For captive females, a peak in fecundity $(20 \%$ probability of conceiving) occurred when individuals were six years old (Blomqvist 1995). Captive male Wolverines matured an average of one year later than females, and attained peak fecundity at seven to nine years of age (Blomqvist 1995).

\section{DISTRIBUTION}

1. Alberta. - Prior to the turn of the century, Wolverines were found throughout the province (Holbrow 1976). However, fur records from 1970 to 1995 show that the recent range extends north of a line between Cold Lake and Edson, and along the eastern slopes of the Rocky Mountains (Figure 1). The majority of Wolverines have been harvested from the northern quarter of the province, and along the foothills in areas outside of Banff, Jasper and Waterton Lakes National Parks, where trapping is prohibited. This pattern corresponds closely with Boyd (1977), who noted that the majority of pelts during the first five years of pelt registration (1970 to 1975) were reported from areas along Alberta's borders with the Northwest Territories and British Columbia. The current range is also consistent with the distribution shown by Smith (1993), but much larger than that of Van Zyll de Jong (1975). This difference is because Van Zyll de Jong (1975) considered Wolverines trapped in central Alberta to represent dispersing juveniles and not residents.
In general, the current range of Wolverines in Alberta corresponds with areas that have relatively low levels of human development.

2. Other Areas. - Historically, the Wolverine was distributed across Canada, with the exception of eastern portions of the maritime provinces. This distribution extended southward into the United States, as far as Illinois and Indiana in the east and New Mexico and California in the west (Kelsall 1989, Seton 1929).

The distribution of Wolverines has been greatly reduced since the turn of the century, especially in the eastern and southern portions of the range (Figure 2; Holbrow 1976, Kelsall 1981). Until recently, the Wolverine was thought to be almost extirpated from eastern Canada, as there were no sightings of Wolverines from Labrador for a period of over 15 years, and few records from Quebec between 1972 and 1982 (Dauphine 1989, Kelsall 1981, Prescott 1983). However, four to five Wolverine per year have been sighted in Quebec in recent years (RENEW 1996), and tracks have recently been reported in Labrador (C. Dauphine, pers. comm.). This suggests that small populations still occur in these areas.

Further west, Wolverines occur in northwestern Ontario, in Manitoba north of $54 \mathrm{~N}$ in areas that have not been cleared or farmed, and in northern Saskatchewan where there are Barrenground Caribou (Banci 1994, Dauphine 1989, Kelsall 1989, Wilson 1982). Wolverines occupy most of British Columbia, although the range is much reduced in southwestern regions of the province due to rural and urban 


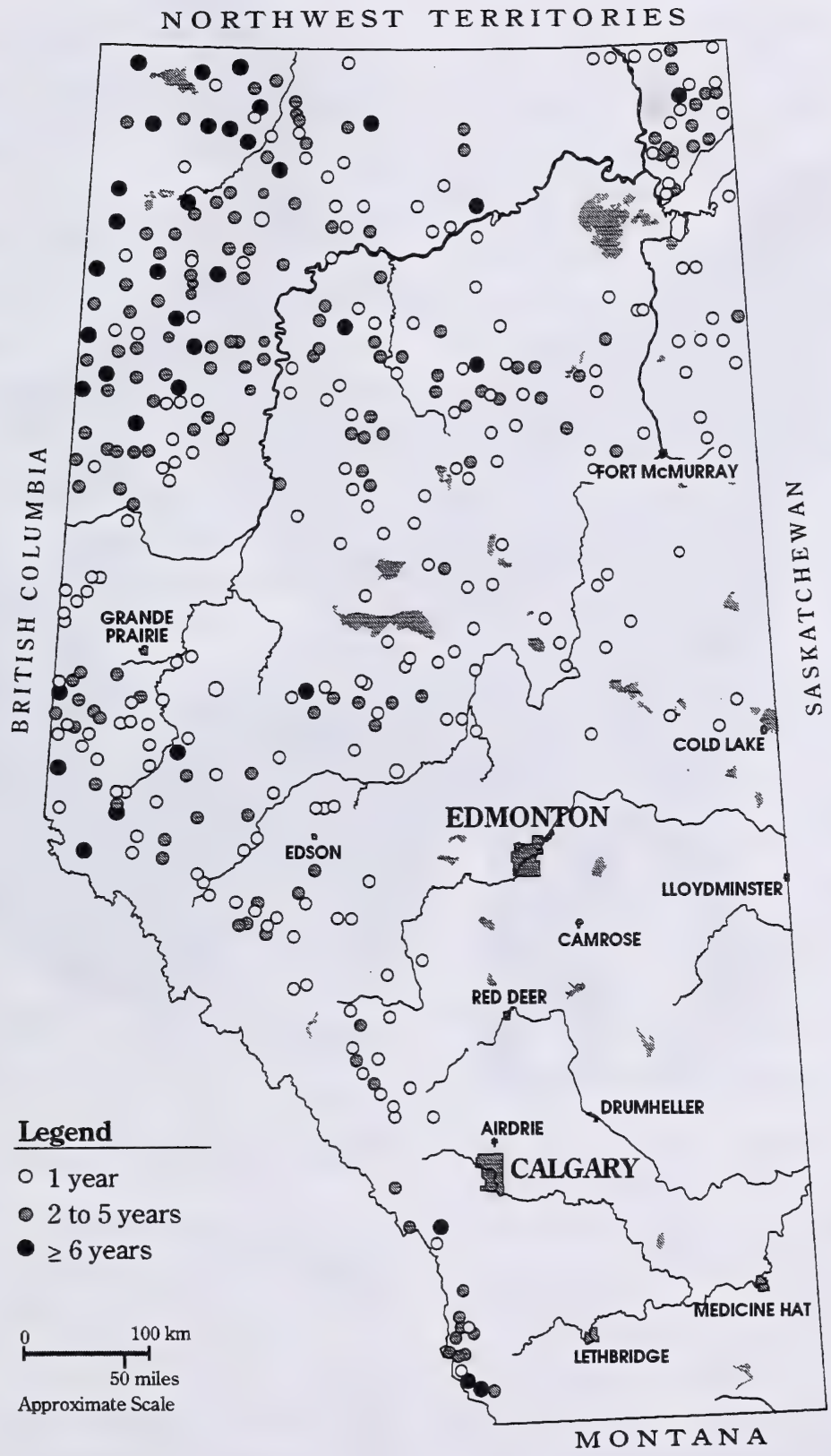

Figure 1. Distribution of the Wolverine in Alberta, according to provincial fur affidavits, 1970-1995. Points are plotted at the centre of each Registered Fur Management Area reporting Wolverines during this period, and are shaded according to the number of years that Wolverines were harvested in each area (see legend). The absence of records in Banff, Jasper and Waterton Lakes National Parks reflects a trapping ban in these areas. 


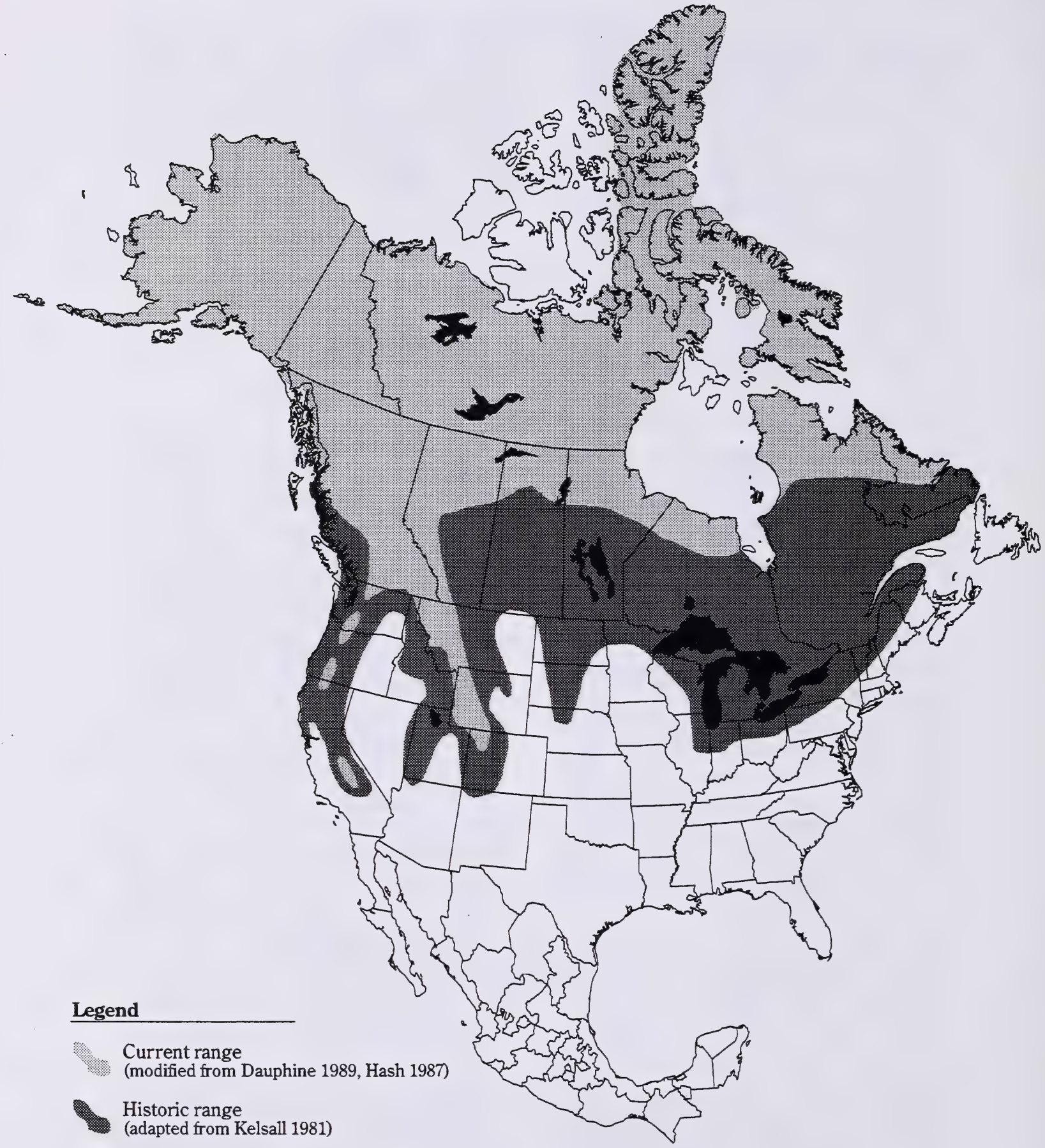

Figure 2. Current and historic ranges of the Wolverine in North America. 
development (Hatler 1989). The entire Northwest Territories and the Yukon support Wolverines (Dauphine 1989, Kelsall 1989).

In the United States, resident populations of Wolverines occur in Alaska and along the Rocky Mountains into Montana, Idaho and Colorado, and along the Cascade Mountains through Washington, Oregon and into California (Banci 1994, Copeland 1996 in Weaver et al. 1996, Hash 1987, Hatler 1989, Wilson 1982). In the last 20 years, some areas of the U.S. along the continental divide have been recolonized from Canada (Wilson 1982).

Data on the distribution of Wolverines in Eurasia are sketchy. The species' range in Scandinavia appears to be concentrated in the mountainous central and northern portions of Norway and Sweden, as well as in Finland (Kvam et al. 1988, Nyholm 1993 and Andersson 1995 in Blomqvist 1995). Wolverines also occupy the taiga and northern coniferous forest of the former Soviet Union (M. S. Blinnikov, pers. comm.).

\section{POPULATION SIZE AND TRENDS}

1. Alberta. - Although the 1996 Status of Alberta Wildlife report (Alberta Wildlife Management Branch 1996) estimates less than 1000 breeding individuals in the province, there have been no specific studies of the Wolverine in Alberta, so no accurate population estimates are available. Trapping records indicate that this species is most common along Alberta's borders with British Columbia and the Northwest Territories, and that density decreases towards the east and south (Figure 1, Boyd 1977). B. Johnson (pers. comm.) indicates that areas northwest of Manning (Wildlife Management Unit 524) and south of Grande Prairie (WMU 356) have produced the most pelts in recent years, and as a whole, Fur Management Zone (FMZ) 2 in the northwestern part of the province typically yields as many pelts in a given year as all other areas of the province combined (Figure 3). In the mountain parks, the Wolverine is considered to be rare (Smith 1993) with approximately 10 Wolverines being sighted per year by back country wardens (W. Bradford, pers. comm.).

Harvest data (Figure 4.) show peaks in the late 1920s, 1970s and 1980s, and an almost steady decline from 1984 to the present. A breakdown of harvest data by Fur Management Zone (FMZ) shows a pronounced decrease in pelts harvested in the past 10 years from the northwestern part of the province (FMZ 2), where the Wolverine is most abundant. The other FMZs show low harvest numbers with no discernable population trend since 1971 .

For a number of reasons, however, fur records may not accurately reflect population trends. First, harvest data may not account for pelts that are used locally. Moreover, because trapping effort can vary greatly from year to year in response to prices of Wolverine pelts, harvest numbers may reflect varying effort, rather than actual abundance. Wolverine harvest may also be affected by prices of other fur-bearing species, if additional effort directed at such species increases the incidental harvest of Wolverines. 
Table 1. Wolverine density estimates from North American studies.

\begin{tabular}{|c|c|c|}
\hline Density estimate & Study area & Reference \\
\hline $1 / 207 \mathrm{~km}^{2}$ & northern British Columbia & Quick 1935 \\
$1 / 65 \mathrm{~km}^{2}$ & Montana & Hornocker and Hash 1981 \\
$1 / 139 \mathrm{~km}^{2}$ & northwestern Alaska & Magoun 1985 \\
$1 / 213 \mathrm{~km}^{2}$ & Alaska & Becker et al. 1992 \\
$1 / 177 \mathrm{~km}^{2}$ & Yukon & Banci and Harestad 1990 \\
$1 / 136-226 \mathrm{~km}^{2}$ & Northwest Territories & Lee and Niptanatiak 1993 \\
\hline
\end{tabular}

An alternative source of information for population trends is trapper opinion surveys. A survey in 1987 indicated that the population was stable north of $56^{\circ} \mathrm{N}$ latitude, but declining elsewhere in the province (Skinner and Todd 1988). In the most recent opinion survey, trappers considered the Wolverine population to be decreasing throughout Alberta (Alberta Environmental Protection 1996).

2. Other Areas. - Estimates of population density of Wolverines from other areas are variable. Although these differences may partly reflect variations in census methodology, all suggest that the species is quite sparsely distributed. In North American studies (Table 1), population estimates range from one Wolverine per $65 \mathrm{~km}^{2}$ in Montana (Hornocker and Hash 1981) to less than one Wolverine per 200 $\mathrm{km}^{2}$ in northern British Columbia (Quick 1935), Alaska (Becker et al. 1992), and the Northwest Territories (Lee and Niptanatiak 1993).

In Eurasia, data on current Wolverine populations are scarce. In Norway, the population was estimated to be 120 to 180 individuals (Kvam et al. 1988), in Sweden less than 100 individuals (Andersson 1995 in Blomqvist 1995), and in Finland approximately 90 individuals (Nyholm 1993 in Blomqvist 1995). In the conservation parks of Russia, the average number of encounters with Wolverine tracks along $10 \mathrm{~km}$ transects ranged from 0.03 to 1.8 (Russian Research Center 1992).

\section{LIMITING FACTORS}

The naturally low population density of Wolverines, coupled with a low reproductive potential, makes the species susceptible to population declines resulting from human activities. Such activities can be grouped into two major classes of human impact: direct and indirect. Direct impacts include trapping, hunting, and rabies-control programs. Indirect impacts include habitat loss and reductions in ungulate populations.

1. Direct Impacts. - Wolverines are trapped in many parts of their range, and this activity has no doubt had an impact on population size in the same areas. In Montana, for example, Hornocker and Hash (1981) believed that trapping was the greatest source of mortality for Wolverine populations. 


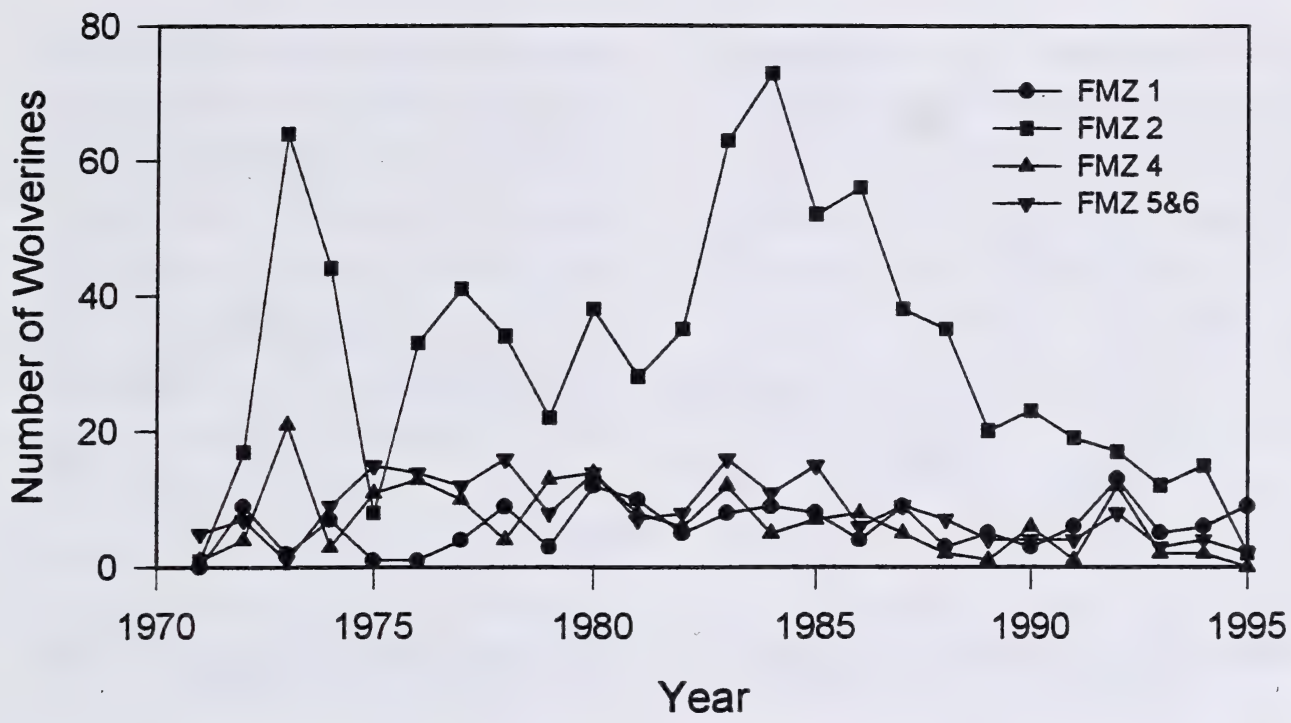

Figure 3. Wolverine harvest by Fur Management Zone (FMZ), 1971 to 1995.

FMZ 1 = northeast; FMZ 2 = northwest; FMZ 4 = west-central;

FMZ 5 \& $6=$ mountains and foothills.

Intuitively, the impacts of trapping should be greatest when fur prices are high (as high as $\$ 254.00$ in 1995-1996). However, the Wolverine population is so small and dispersed that the species is rarely the target of specific trapping efforts (Dauphine 1989). More likely, Wolverine harvest increases when the price of more common furbearers, which require the same size of traps, is high (Dauphine 1989).

Trapping may also impact reproductive success by causing a shortage of male Wolverines (Hatler 1989, Lee 1994, Magoun 1985, Rausch and Pearson 1972). In this species, males have much larger home ranges than females, and several females may occur within the range of a single male (Banci 1987, Gardner 1985, Hornocker and Hash 1981, Magoun
1985). Because males travel greater distances than females, they may be more prone to encountering traps. Thus, the loss of a single male may impact reproductive success of several females in the area.

In the 1950 s, a rabies-control program in Alberta may have caused a reduction in the provincial population. Ballantyne (1958) noted that along with 5,461 wolves culled over the four years of this program, a single Wolverine was killed. However, Kelsall (1968) found that predator control programs in the Northwest Territories, using similar methods as the Alberta rabies-control campaign, killed one Wolverine per 8.5 Wolves. This suggests that Ballantyne's estimate for Alberta may be far below the actual number of Wolverines poisoned during that program. 


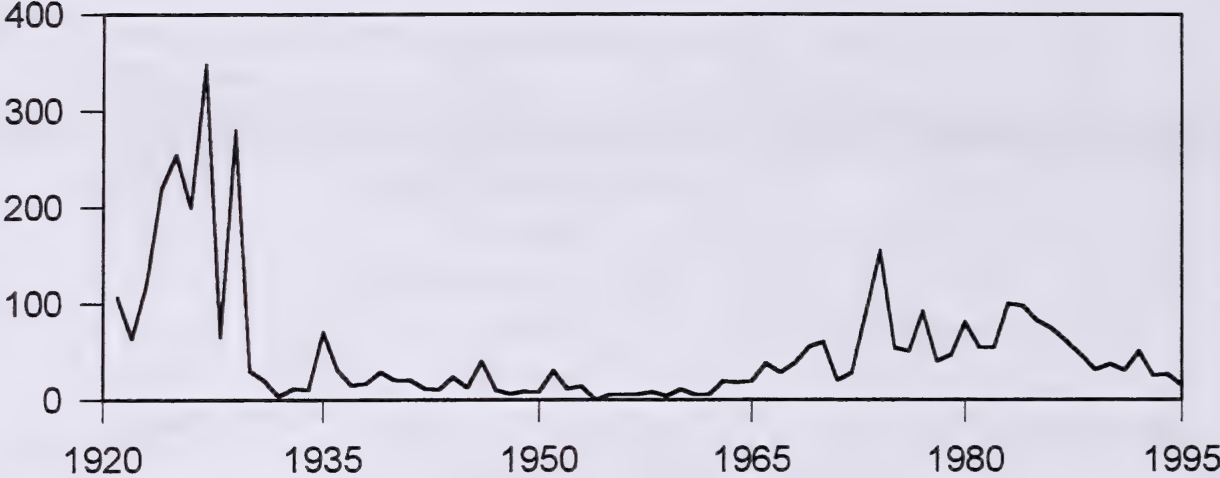

Year

Figure 4. Wolverine harvest in Alberta, 1921 to 1995. Data through 1978 are from Todd and Geisbrecht (1979), more recent data are from provincial fur affidavits.

Given the low reproductive output of Wolverines, recovery from a substantial reduction in numbers, if it occurred, may have taken decades (A. Todd, pers. comm.).

In the absence of accurate information on the density of Wolverines in Alberta, the impacts of trapping and predator control programs remain difficult to assess.

2. Indirect Impacts. - Research has shown that habitat loss is also an important factor currently affecting Wolverine numbers (Hornocker and Hash 1981, Kelsall 1981, Pasitschniak-Arts and Lariviere 1995). Banci (1994) comments that "Wolverines seem to have been most affected by activities that fragment and supplant habitat, such as human settlement, extensive logging, oil and gas development, mining, recreational developments and the accompanying access". More generally, other researchers conclude that Wolverines avoid human contact and therefore human settlement has contributed to reducing the range of
Wolverines (Banfield 1974, Dauphine 1989, Kelsall 1981, Van Zyll de Jong 1975).

Large reductions in the ungulate prey base by humans before the turn of the century, are thought to have aided in the reduction of the Wolverines' range (Dauphine 1989, Holbrow 1976). Large declines in Caribou populations in Quebec and Labrador have been correlated with declines in Wolverine pelt harvests (Dauphine 1989). In Scandinavia, the management of ungulates has been implicated in the decline of Wolverines by reducing the amount of carrion available (Landa and Skogland 1995).

The extent to which habitat loss and changes in ungulate populations limit Wolverine populations in Alberta is unknown. It is certainly likely that these two factors played an important role in the extirpation of this species on the prairies following human settlement. The impacts of more recent land-use changes (e.g., agriculture, forest harvest, oil and gas 
development) on Wolverine populations in the foothills and in northern areas of the province remains to be seen. However, it is clear that contact with humans has eroded the edge of the species' range on a provincial and global scale. With an everexpanding human population, there may be a time when most Wolverine populations will be restricted to large protected areas like the proposed carnivore conservation areas (Hummel 1990), or to areas included in the Yellowstone to Yukon project. These proposals are aimed at setting aside areas large enough to protect viable populations of species, like Wolverines, which require large areas of wilderness.

\section{STATUS DESIGNATIONS}

1. Alberta - In 1991, the Wolverine was included on the "Blue List" of species which may be at risk in the province (Alberta Fish and Wildlife 1991). This designation was assigned because of reduced harvests and unknown population status. The "Blue List" designation was maintained in a 1996 review (Alberta Wildlife Management Division 1996), because of the naturally low population size, an aversion to humans, and because there was too little information to clearly define the status of the species in the province. The Wolverine is also designated as a "fur-bearing animal" in Alberta (Alberta Environmental Protection 1995), and is subject to trapping quotas and other harvest restrictions.

2. Other Areas. - For management purposes, western and eastern populations of Wolverines in Canada are arbitrarily separated by a line running south from Hudson Bay. The western population is considered to be "vulnerable" by the Committee on the Status of Endangered Wildlife in Canada (COSEWIC), because healthy populations exist in British Columbia and the northern territories (Dauphine 1989, RENEW 1996). The eastern population of Wolverine is officially listed as "endangered" by COSEWIC (Dauphine 1989) and a team has been formed to develop a recovery plan (RENEW 1994). Presently, the team, is studying large ungulate populations to determine if their numbers are responsible for differences in the size of eastern and western populations of Wolverines (RENEW 1996).

Globally, the Wolverine is considered to be a "vulnerable" species (World Conservation Monitoring Center 1996), indicating that it faces a high risk of extinction in the wild in the next 10 years. In Norway, Sweden and Finland, Wolverines are considered to be "endangered", and legislation and penalties have been established to protect local populations (Blomqvist 1995). Some groups in the United States are lobbying to list the Wolverine as "threatened" or "endangered" in all of the 48 contiguous states. However, the species has not yet been listed under the federal Endangered Species Act due to insufficient data concerning their population size and risk of extinction (Kucera and Zielinski 1995). Alaska and Montana are the only states that allow trapping of Wolverines, and Montana limits the harvest to one animal per trapper per year. 


\section{RECENT MANAGEMENT IN ALBERTA}

The Wolverine is classified as a furbearer, which allows for limited management by means of harvest quotas, closures and regulated trapping seasons (Alberta Environmental Protection 1995). Presently, the season is restricted to 1 November to 31 January in most management areas, which corresponds to the period when the fur is in prime condition. As well, there is an official quota of one animal per Registered Fur Management Area in most Fur Management Zones to allow problem animals to be removed (B. Johnson, pers. comm.). Two zones (FMZ 7 and 8), which are in the southeastern part of the province and outside of the species' normal range, are closed for Wolverine harvest (Alberta Environmental Protection 1995).

Other than population management through harvest regulations, there have been no specific research or management activities focusing on the Wolverine in Alberta.

\section{SYNTHESIS}

The Wolverine was once distributed across most of Canada and the northern United States, as well as throughout Scandinavia and northern Asia. In eastern Canada, populations are now at very low levels, and western populations have retreated to northern areas and along the Rocky Mountains. In Alberta, Wolverines were once found throughout the province, but now are found only in areas relatively free of human activity.

The population size and reproductive output of Wolverines is naturally low and populations throughout the range occur at relatively low densities. Threats to the Wolverine population in Alberta include trapping, development of wilderness areas and activities that reduce the amount of carrion available during the winter.

In Alberta, almost all information on Wolverine populations has been derived from trapping records, and these data probably do not accurately reflect population size or trends in the province. Thus, it is nearly impossible to determine accurately the provincial status of this species, and to assess whether potential threats to local populations place the species in danger of future declines or range contractions. There is clearly a need for further research into the biology and management of Wolverines in Alberta. To be most useful, this information should be obtained from sources other than trapping records (e.g., telemetry, direct observation). Such studies would be extremely challenging, but would go a long way in gaining a more complete understanding of this species in Alberta. 


\section{LITERATURE CITED}

Alberta Environmental Protection. 1995. Alberta trapping guide 1995-96. Alberta Natural Resources Service, Edmonton, AB. 24 pp.

Alberta Environmental Protection. 1996. Summary of the 1994 questionnaire of registered trappers in Alberta. Alberta Natural Resources Service, Edmonton, AB. $131 \mathrm{pp}$.

Alberta Fish and Wildlife. 1985. A policy for the management of threatened wildlife in Alberta. Alberta Fish and Wildlife, Edmonton, AB. 34 pp.

Alberta Fish and Wildlife. 1991. The status of Alberta wildlife. Alberta Fish and Wildlife, Edmonton, AB. 44 pp.

Alberta Wildlife Management Division. 1996. The status of Alberta wildlife. Alberta Natural Resources Service, Edmonton, AB. 44 pp.

Andersson, T. B. 1995. "De Fyras gang" vaxer. Land 3: 14-15.

Banci, V. A. 1987. Ecology and behavior of Wolverine in Yukon. Unpubl. M.Sc. thesis, University of British Columbia. Vancouver, BC. $178 \mathrm{pp}$.

Banci, V. A. 1994. Wolverine. Pp. 99-127 in The scientific basis for conserving forest carnivores in the western United States. (L. F. Ruggiero, K. B. Aubry, S. W. Buskirk, L. J. Lyon and W. J. Zielinski, eds.). U.S.D.A. For. Serv. Gen. Tech. Rep. RM-254, Fort Collins, $\mathrm{CO}$.
Banci, V., and A. S. Harestad. 1990. Home range and habitat use of Wolverines Gulo gulo in Yukon, Canada. Holarctic Ecology 13: 195-200.

Banfield, A. W. F. 1974. The mammals of Canada. University of Toronto Press, Toronto, ON. $438 \mathrm{pp}$.

Ballantyne, E. E. 1958. Rabies control in Alberta wildlife. Vet. Med. 23: 87-91.

Becker, E. F., and C. Gardner. 1992. Wolf and Wolverine density estimation techniques. Federal Aid in Wildlife Restoration, Project W-23-5. Alaska Dept. of Fish and Game, Juneau, AK. 31 pp.

Blomqvist, L. 1995. Reproductive parameters of Wolverines (Gulo g. gulo) in captivity: Ann. Zool. Fennici 32: 441444.

Boles, B. K. 1977. Predation by wolves on Wolverines. Can. Field-Natur. 91: 6869.

Boyd, M. 1977. Analysis of fur production records by individual fur-bearing species for registered trapping areas in Alberta, 1970-75. Alberta Fish and Wildlife Division, Edmonton, $\mathrm{AB} .72$ pp.

Burkholder, B. L. 1962. Observations concerning Wolverine. J. Mammal. 43: 263-264.

Copeland, J. P. 1996. Biology of the Wolverine in central Idaho. Unpubl. M.Sc. thesis, University of Idaho, Moscow, ID. 
COSEWIC. 1996. Canadian species at risk. Committee on the Status of Endangered Wildlife in Canada, Ottawa, ON. $18 \mathrm{pp}$.

Dauphine, T. C. 1989. Updated status report on the Wolverine (Gulo gulo) in Canada. Committee on the Status of Endangered Wildlife in Canada. Ottawa, ON. 25 pp.

Doyle, F. I. 1995. Bald Eagle, Haliaeetus leucocephalus, and Northern Goshawk, Accipiter gentilis, nest apparently preyed upon by a Wolverine(s), Gulo gulo, in the southwestern Yukon territory. Can. Field-Natur. 109: 115116.

Gardner, C. L. 1985. The ecology of Wolverines in south-central Alaska. Unpubl. M.Sc. thesis, University of Alaska. Fairbanks, AK. 82 pp.

Gardner, C. L., W. B. Ballard, and R. H. Jessup. 1986. Long distance movement by an adult Wolverine. J. Mammal. 67: 603.

Haglund, B. 1966. Winter habits of the Lynx (Lynx lynx L.) and Wolverine (Gulo gulo L.) as revealed by tracking in the snow. Viltrevy 4: 81-299.

Hall, E.R. 1926. The abdominal skin gland of Martes. J. Mammal. 7: 227-229.

Hardy, T. M. P. 1948. Wolverine fur frosting. J. Wild. Manage. 12: 331-332.

Hash, H. S. 1987. Wolverine. Pp. 575-585 in Wild fur-bearer management and conservation in North America. (M. Novak, J. A. Baker, M. E. Obbard, and
B. Malloch, eds.). Ontario Trappers Association, North Bay, ON.

Hatler, D. F. 1989. A Wolverine management strategy for British Columbia. B. C. Ministry of Environment, Wildlife Branch, Wildlife Bull. No. B-60, Victoria, BC. 124 pp.

Holbrow, W. C. 1976. The biology, mythology, distribution and management of the Wolverine (Gulo gulo L.) in western Canada. Unpubl. M.Sc. thesis, University of Manitoba, Winnipeg, MB. 214 pp.

Hornocker, M. G., and H. S. Hash. 1981. Ecology of the Wolverine in northwestern Montana. Can. J. Zool. 59: 1286-1301.

Hummel, M. 1990. A conservation strategy for large carnivores in Canada. World Wildlife Fund Canada. Toronto, ON. 98 pp.

Kelsall, J. P. 1968. The migratory Barrenground Caribou of Canada. Canadian Wildlife Service, Ottawa, ON. 340 pp.

Kelsall, J. P. 1981. Status report on the Wolverine (Gulo gulo) in Canada in 1981. Committee on the Status of Endangered Wildlife in Canada, Ottawa, ON. 47 pp.

Koehler, G. M., M. G. Hornocker, and H.

S. Hash. 1980. Wolverine marking behavior. Can. Field-Natur. 94: 339-341.

Krott, P. 1959. Demon of the north. Hutchinson and Co. Ltd., London, UK. $232 \mathrm{pp}$. 
Kucera, T. E., and W. J. Zielinski. 1995. The case of forest carnivores: small packages, big worries. Endangered Species Update 12(3). URL: http//nceet.snre.umich.edu/EndSpp/ ESupdate.carnivores.html.

Kvam, T., K. Overskaug, and O. J. Sorensen. 1988. The Wolverine Gulo gulo in Norway. Lutra 31: 7-27.

Landa, A., and T. Skogland. 1995. The relationship between population density and body size of Wolverines Gulo gulo in Scandinavia. Wildlife Biology 1: 165175.

Lee, J. 1994. Wolverine harvest and carcass collection Coppermine, Bay Chimo and Bathurst Inlet, 1992/93. Manuscript \#76, Northwest Territories Dept. of Renewable Resources. Yellowknife, NWT. 15 pp.

Lee, J., and A. Niptanatiak. 1993. Ecology of the Wolverine on the central arctic barrens. Manuscript \# 75, Northwest Territories, Dept. of Renewable Resources. Yellowknife, NT. 29 pp.

Lee, J., and A. Niptanatiak. 1996. Observation of repeated use of a Wolverine, Gulo gulo, den on the tundra of the Northwest Territories. Can. FieldNatur. 110: 349-350.

Liskop, K. S., R. M. S. F. Sadleir, and B. P. Saunders. 1981. Reproduction and harvest of Wolverine (Gulo gulo) in British Columbia. Worldwide Furbearer Conference Proceedings 1: 469477.
Magoun, A. J. 1985. Population characteristics, ecology, and management of Wolverine in northwestern Alaska. Unpubl. Ph.D. thesis, University of Alaska, Fairbanks, AK. 197 pp.

Magoun, A. J., and P. Valkenburg. 1983. Breeding behavior of free-ranging Wolverines (Gulo gulo). Acta Zool. Fenn. 174: 175-177.

Mead, R. A., M. Rector, G. Starypan, S. Neirinckx, M. Jones, and M. N. Don Carlos. 1991. Reproductive biology of captive Wolverines. J. Mammal. 72: 807-814.

Mehrer, C. F. 1976. Gestation period in the Wolverine, Gulo gulo. J. Mammal. 57: 570 .

Myhre, R., and S. Myrberget. 1975. Diet of Wolverines (Gulo gulo) in Norway. J. Mammal. 56: 752-757.

National Research Council. 1995. Science and the Endangered Species Act. National Academy Press, Washington, DC. $271 \mathrm{pp}$.

Nyholm, E. 1993. Jarven I Finlands natur. Jagaren 6: 14-15.

Pasitschniak-Arts, M. and S. Lariviere. 1995. Gulo gulo. Mammalian Species 499: 1-10.

Prescott, J. 1983. Wolverine, Gulo gulo, in Lake St. John area, Quebec. Can. FieldNatur. 97: 457-458. 
Pulliainen, E. 1968. Breeding biology of the Wolverine (Gulo gulo L.) in Finland. Ann. Zool. Fenn. 5: 338-344.

Quick, H. F. 1952. Some characteristics of Wolverine fur. J. Mammal. 33: 492-493.

Quick, H. F. 1953. Wolverine, fisher, and marten studies in a wilderness region. Trans. N. Amer. Wildl. Conf. 18: 513532.

Rausch, R. A. and A.M. Pearson. 1972. Notes on the Wolverine in Alaska and the Yukon Territory. J. Wild. Manage. 36: 249-268.

RENEW. 1994. Report \#4. Recovery of Nationally Endangered Wildlife, Ottawa, ON. 29 pp.

RENEW. 1996. RENEW fifth annual report 1994-95. Recovery of Nationally Endangered Wildlife, Ottawa, ON. 34 pp.

Russian Research Center. 1996. Strict nature reserves (Zapovedniki) of Russia: collection of "Chronicles of Nature" data for 1991-1992. (A. E. Volkov, ed.). Sabashinikovs Publishers, Moscow. 270 pp.

Seton, E. T. 1929. Lives of game animals, vol. 2. Doubleday and Co., New York, NY. $746 \mathrm{pp}$

Smith, H. C. 1993. Alberta mammals: an atlas and guide. Provincial Museum of Alberta, Edmonton, AB. 238 pp.
Todd, A. W. and L. C. Geisbrecht. 1979. A review of Alberta fur production and management, 1920-21 to 1977-78. Alberta Energy and Natural Resources. Fish and Wildlife Division, Edmonton, AB. 38 pp.

Van Zyll de Jong, C. G. 1975. The distribution and abundance of the Wolverine (Gulo gulo) in Canada. Can. Field-Natur. 89: 431-437.

Weaver, J. L., P. C. Paquet, and L. F. Ruggiero. 1996. Resilience and conservation of large carnivores in the Rocky Mountains. Conserv. Biol. 10: 964-976.

Whitman, J. S., W. B. Ballard, and C.L. Gardner. 1986. Home range and habitat use by Wolverines in south-central Alaska. J. Wild. Manag. 50: 460-462.

Wilson, D. E. 1982. Wolverine. Pp. 644652 in Wild mammals of North America: biology, management, and economics. (J. A. Chapman and G. A. Feldhamer, eds.). John Hopkins University Press, Baltimore, MD.

World Conservation Monitoring Center. 1996. URL: http//www.wcmc.org.uk/species/animals/categories.html (revision date: 17 Oct. 96).

Wright, P. L., and R. L. Rausch. 1955. Reproduction in the Wolverine, Gulo gulo. J. Mammal. 36: 346-355. 


\section{A. Status of Alberta Wildlife color lists (after Alberta Wildlife Management Division 1996)}

\begin{tabular}{|l|l|}
\hline Red & $\begin{array}{l}\text { Current knowledge suggests that these species are at risk. These species have declined, or are } \\
\text { in immediate danger of declining, to nonviable population size }\end{array}$ \\
\hline Blue & $\begin{array}{l}\text { Current knowledge suggests that these species may be at risk. These species have undergone } \\
\text { non-cyclical declines in population or habitat, or reductions in provincial distribution }\end{array}$ \\
\hline Yellow & $\begin{array}{l}\text { Species that are not currently at risk, but may require special management to address concerns } \\
\text { related to naturally low populations, limited provincial distributions, or demographic/life } \\
\text { history features that make them vulnerable to human-related changes in the environment }\end{array}$ \\
\hline Green & $\begin{array}{l}\text { Species not considered to be at risk. Populations are stable and key habitats are generally } \\
\text { secure }\end{array}$ \\
\hline Undetermined & Species not known to be at risk, but insufficient information is available to determine status \\
\hline
\end{tabular}

\section{B. Alberta Wildlife Act}

Species designated as "endangered" under the Alberta Wildlife Act include those defined as "endangered" or "threatened" by $A$ Policy for the Management of Threatened Wildlife in Alberta (Alberta Fish and Wildlife 1985):

\begin{tabular}{|l|l|}
\hline Endangered & A species whose present existence in Alberta is in danger of extinction within the next decade \\
\hline Threatened & $\begin{array}{l}\text { A species that is likely to become endangered if the factors causing its vulnerability are not } \\
\text { reversed }\end{array}$ \\
\hline
\end{tabular}

\section{Committee on the Status of Endangered Wildlife in Canada (after COSEWIC 1996)}

\begin{tabular}{|l|l|}
\hline Extirpated & A species no longer existing in the wild in Canada, but occurring elsewhere \\
\hline Endangered & A species facing imminent extirpation or extinction \\
\hline Threatened & A species likely to become endangered if limiting factors are not reversed \\
\hline Vulnerable & $\begin{array}{l}\text { A species of special concern because of characteristics that make it particularly sensitive to } \\
\text { human activities or natural events }\end{array}$ \\
\hline Not at Risk & A species that has been evaluated and found to be not at risk \\
\hline Indeterminate & A species for which there is insufficient scientific information to support status designation \\
\hline
\end{tabular}

\section{United States Endangered Species Act (after National Research Council 1995)}

\begin{tabular}{|l|l|}
\hline Endangered & Any species which is in danger of extinction throughout all or a significant portion of its range \\
\hline Threatened & $\begin{array}{l}\text { Any species which is likely to become an endangered species within the foreseeable future } \\
\text { throughout all or a significant portion of its range }\end{array}$ \\
\hline
\end{tabular}




\section{List of Titles In This Series}

(as of September 1997)

No. 1 Status of the Piping Plover (Charadrius melodus) in Alberta, by David R. C. Prescott. 19 pp.

No. 2 Status of the Wolverine (Gulo gulo) in Alberta, by Stephen Petersen. $17 \mathrm{pp}$.

No. 3 Status of the Northern Long-eared Bat (Myotis septentrionalis) in Alberta, by M. Carolina Caceres and M. J. Pybus. 19 pp.

No. 4 Status of the Ord's Kangaroo Rat (Dipodomys ordii) in Alberta, by David L. Gummer. 16 pp.

No. 5 Status of the Eastern Short-horned Lizard (Phrynosoma douglassii brevirostre) in Alberta, by Janice D. James, Anthony P. Russell and G. Lawrence Powell. 20 pp.

No. 6 Status of the Prairie Rattlesnake (Crotalus viridis viridis) in Alberta, by Sheri M. Watson and Anthony P. Russell. 26 pp.

No. 7 Status of the Swift Fox (Vulpes velox) in Alberta, by Susan E. Cotterill. 17pp.

No. 8 Status of the Peregrine Falcon ( Stepnisky. In Preparation.

No. 9 Status of the Northern Leopard Frog (Rana pipiens) in Alberta, by Greg Wagner. In Preparation.

No. 10 Status of the Sprague's Pipit (Anthus spragueii) in Alberta, by David R. C. Prescott. 14 pp.

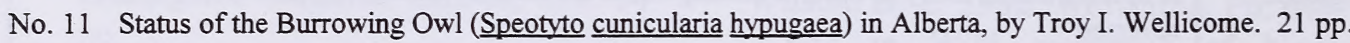


National Library of Canada
Bibliotheqque nationale du Canada

33286513566857 